\title{
Review
}

\section{Defining the Phygital Marketing Advantage}

\author{
Matt Johnson and Rob Barlow *(D) \\ Hult International Business School, San Francisco, CA 94111, USA; matt.johnson@faculty.hult.edu \\ * Correspondence: robert.barlow@faculty.hult.edu
}

check for

updates

Citation: Johnson, M.; Barlow, R. Defining the Phygital Marketing Advantage. J. Theor. Appl. Electron. Commer. Res. 2021, 16, 2365-2385. https: / / doi.org/10.3390/ jtaer16060130

Academic Editor: Shib Sankar Sana

Received: 31 July 2021

Accepted: 8 September 2021

Published: 14 September 2021

Publisher's Note: MDPI stays neutral with regard to jurisdictional claims in published maps and institutional affiliations.

Copyright: (c) 2021 by the authors. Licensee MDPI, Basel, Switzerland. This article is an open access article distributed under the terms and conditions of the Creative Commons Attribution (CC BY) license (https:/ / creativecommons.org/licenses/by/ $4.0 /)$.

\begin{abstract}
Interest in the application of phygital marketing to retail commerce has increased in recent years. Implicit in this excitement is the notion that physical experiences provide unique value above and beyond what can be offered via digital means, and therefore that combining the two can galvanize sales. However, the specific sources of this marketing potential remain undertheorized and the factors determining the appropriateness of such implementations remain unclear. Based on an extensive review of relevant literatures, we begin by considering a particularly important potential source of phygital marketing's power. Specifically, we bring together findings from consumer psychology and neuroscience to provide a mechanistic account explaining how the combination of reduced "pain of payment", facilitated by digital purchasing technologies, and the product attachment generated by real or simulated product experiences prior to purchase holds the potential to increase sales. We then propose a more general theoretical framework grounded on a review of primary and secondary research findings from consumer psychology and consumer neuroscience to explain the potential power of phygital marketing experiences, account for their unique value, and provide a platform for future research. The paper equips both academics and practitioners with a better and more scientific understanding of the practical dimensions of phygital commerce and lays a foundation for future enquiry.
\end{abstract}

Keywords: phygital; digital; marketing; product experience; pain of paying; psychology; neuroscience

\section{Introduction}

The concept of "phygital" consumption experiences is relatively new, reflecting the novelty of the emerging digital technologies that empower them [1,2]. Phygital marketing involves crafting a consumer journey that integrates physical and digital experiences in a seamless way, creating experiences that are only possible due to the rise of emerging digital technologies [3]. For example, popular phygital approaches involve incorporating contactless payment systems, interactive touch screens, seamless digital payment systems, and augmented reality into the customer experience [4,5]. Ultimately, the use of such strategies has a wide application across industries (e.g., education, tourism, banking, etc.), but we focus exclusively on retail applications here.

There is significant excitement about the proliferation of phygital marketing in the future of retail commerce [6,7]. While research on the subject is still nascent, early work has found that phygital experiences can be designed to provide a novel and seamless experience that users enjoy, influencing customer perceptions of product value while generating trust and minimizing confusion [8]. In this paper, we review relevant findings from the literatures on retail consumer purchasing behavior, including work on the underlying psychology and neuroscience that helps to explain it, in order to better understand the role that technological innovations, including digital sensing technologies and the rise of augmented and virtual reality, can play in compensating for challenges that arise out of the digital purchasing environment. Presumably, these technologies hold potential to combine many appealing features of the "in person" purchasing experience with the ease of digital search and payment, an exciting and increasingly common combination that has recently been referred to as a "phygital revolution" [9]. 
Implicit in the excitement about phygital marketing is that physical experiences provide unique value above and beyond what can be offered via digital means. However, the specific sources of this marketing potential remain undertheorized, and the factors determining the appropriateness of such strategies from the standpoint of their capacity to increase sales and net ROI remain unclear. In this paper, we review relevant theoretical models and research findings in consumer psychology and consumer neuroscience with direct application to these issues. Grounded by this literature, we develop a theoretical framework to help explain the potential power of phygital marketing experiences, accounting for their unique value. In doing so, our overarching goal is to equip academics and practitioners with a scientific and practically useful understanding of the dimensions contributing to the potential value of such approaches when integrated as part of a company's retail marketing strategies. Based on the findings of our review, we develop an account isolating two elements of the consumer experience as particularly important factors contributing to phygital marketing's power: the pre-purchase product experience and the payment experience. Specifically, we argue that these dimensions comprise a primary source of phygital marketing's contribution to mental gain and loss calculations dictating retail consumers' purchasing decisions. We conclude by outlining a more general set of criteria contributing to these calculations, based on the extensive review of relevant literatures, and pose further questions for direct empirical testing and research.

We begin by narrowing the focus of the paper, identifying two "phygital ideal types" from among the multitude of possibilities that typify the "phygital revolution" that will receive our attention in the review and analysis. These ideal types include phygital marketing strategies using automated sensing technologies and simulated in-person experiences. Next, we review work on the psychology and neuroscience of consumer behavior at the point of purchase, drawing on extensive findings in these literatures to explain why reintroducing physical product experiences to the digital retail environment contributes to increased product attachment. Drawing on these insights, we argue that, when combined with the decreased "pain of paying" native to digital purchasing, these effects are among the leading factors that contribute to phygital marketing's unique power. Finally, we synthesize the key insights from this review to propose a more general framework describing the elements included within "gain" and "cost" calculations contributing to retail consumer decision-making at the point of purchase.

\section{Phygital Ideal Types}

The general category of phygital product experiences includes a potentially vast range of permutations. In this paper, we confine our analysis to a pair of "ideal types" representing a large proportion of possible cases.

The first of these involves use of digital sensing technology to automate in-person processes that are often a primary source of consumer dissatisfaction. We refer to such cases in the rest of the paper as automated sensing technologies ("ASTs"). This set of innovations is exemplified in Amazon Go stores, where payment for goods is immediately extracted from the customer's digital wallet once they leave the store, without need for traditional cashiers or even "self-checkout". Digital sensing technologies and artificial intelligence combine to track the items removed from shelves by individual customers who are billed to their accounts without any need for additional action on their part. Similarly, some commentators envision a future in which trying on clothes in person is a more seamless experience, with consumers entering a changing room and having access to digital technologies that will allow them to select types, styles, and sizes of clothing and have them directly delivered to try on. In these cases, digital technologies are imported into the in-person experience, helping to alleviate some of the most frustrating elements of that environment.

Amazon alone intends to open up to 3,000 Amazon Go stores within the next several years [10]. However, they will soon have competition: Alibaba, JD.com, and 7-Eleven are among the hundreds of retailers who already have or intend to deploy similar stores over a similar time frame [11]. Alongside Amazon and its contractors, there are currently over 
150 companies focused in different technological areas working on automated, cashierless, brick and mortar retail [11]. Over the long term, these systems offer opportunities to reduce overhead costs, improve the efficiency of inventory management, gather shopper data, and improve customer satisfaction due to reduced wait times. Furthermore, consumers who try the experience overwhelmingly report enjoying it: of the 28 percent of respondents to a nationwide survey who said they had gone to an Amazon Go, fully 89 percent reported enjoying the experience, while more than half of all respondents said they would like to see a similarly tech-enabled store near them [10].

However, digital sensing technologies can facilitate a more efficient in-store experience in other ways as well. For example, in the wake of COVID-19, makeup retailers Sephora and Ulta have decided to prohibit customers from physically testing products on their skin. Though the logic of the decision is primarily dictated by safety concerns, the introduction of in-store AR alternatives by both brands has not only addressed those concerns but helped open up a wider array of alternatives to consumers who no longer need to apply and remove makeup in order to see how it will look, but instead can use in-store kiosks to trial millions of shades and brands. For example, Ulta's tool—called "GLAMlab"—has seen a seven-fold increase in engagement rates since the advent of the pandemic and now boasts more than 50 million shades of foundation for consumers to try before they buy [12].

A second, no less impactful set of phygital innovations relate to the use of augmented and virtual reality technologies to "import" digital artifacts into the physical world for consumers to interact with and evaluate in person before purchasing. We refer to these as simulated in-person experiences ("SIPs"). In such cases, consumers can have a simulated experience of goods in the comfort of their homes without giving up the ease of digital searching and payment. Rather than try on clothes in person, for example, customers can see what they look like in 3d and even "try them on" using AR and VR technologies. These technologies may be put to similar use with other kinds of products, including housewares or appliances, which may be visualized within the home environment, or technology products themselves, which users will be able to handle and "use" before they are even released to the public.

Consumers have demonstrated considerable openness to using AR/VR technologies to enhance their shopping experiences both online and in person. In a recent Neilson global poll, global consumers listed AR/VR as "the top technology they're seeking to assist, amplify, and augment their daily lives" [13]. In fact, in the same poll, 51 percent of respondents specifically indicated they are willing to use such technologies to assess products prior to purchasing. Furthermore, these technologies have proven to be effective sales tools: the e-commerce company Shopify reports that interactions with products through AR technology resulted in 94 percent higher conversion rates than in those using conventional imagery and video to market products [12]. In another study, marketing campaigns using AR were found to have an average dwell time of $75 \mathrm{~s}$ (traditional radio and TV ads have dwell times of just $2.5 \mathrm{~s}$ ), and $71 \%$ of shoppers claim they would shop at a retailer more often if they were offered AR. The retail industry's spending on AR and VR is expected to increase at a compound annual growth rate of $238.7 \%$. As a result, it will become the sector spending most on AR and VR by the early 2020s [14].

\section{Methods}

The starting point of our review and investigation into the impact of these technologies is the well-established consumer neuroscience finding that fMRI and EEG can be used to track brain-based indicators of perceived "gains and costs" contributing to consumer decisions during the purchasing experience. Researchers have found that these results can be used to predict purchase likelihood with considerable accuracy [15]. Our aim in conducting this review is to understand how the addition of phygital technologies to the consumer purchasing experience will alter these internal calculations and may, therefore, lead to changes in consumer behavior. We draw on a body of existing primary and secondary research findings to explain how disparate findings on consumer purchasing 
behavior may be situated within such a framing and how emergent phygital technologies may impact them, with the aim of sketching a preliminary theoretical framework that may be used to situate and orient subsequent inquiry.

Our research began with a search for articles, books, book chapters, and trade publications on or related to the phenomenon of phygital marketing, with a specific focus on research pertaining to the AST and SIP ideal types described above. To conduct this search, we used Google Scholar and the Hult International Business School library databases. We used the resulting primary list of collected sources to compile additional references through bibliographic analysis and identification of relevant materials. Eligible sources for inclusion in our review included academic articles, books, book chapters, and trade publications from disparate disciplinary areas, including business, consumer psychology, and consumer neuroscience.

The search terms used to build our initial base of resources included the following: "phygital marketing," "cashierless payment," "Amazon GO," "digital sensing retail," "augmented reality retail," "AR retail," "virtual reality retail," and "VR retail." In many cases, different combinations of the terms described above were also used. Additional searches added the terms "neuroscience," "psychology," and "pain of paying" to the primary list. Initial sorting of these searches was carried out through analysis of abstracts and reviews for suitability.

Our initial analysis of the resources collected through this process involved reading them while paying close attention to additional, secondary sources cited to support important claims, which were then sourced and assessed for suitability of inclusion in our collection. The latter step was a crucially important part of the process because phygital marketing is an emergent phenomenon that is not yet subject to systematic study and therefore lacks a coherent "literature," meaning that our findings were interdisciplinary by necessity. The bulk of the collected works fell within the disciplines of business, psychology, and neuroscience, though a limited number were published in behavioral economics.

The collection of articles, books, book chapters, and popular press articles collected by means of this strategy were analyzed with specific attention to identifying:

1. Trends and patterns relating to the deployment of ASTs and SIPs, including work focusing on:

- consumer attitudes towards such technologies (inside and outside of a retail setting) and

- business outcomes connected with the use of such technologies in a retail setting, as well as:

2. Identification of theoretical arguments (justified by primary or secondary research) for the role that prominent research findings in related literatures from neuroscience and psychology could play in explaining these consumer attitudes and practical business effects.

Based on our analysis of these articles, we synthesized and developed a general framework describing the dimensions potentially impacted by the introduction of ASTs and SIPs at the point of retail purchase and reported on specific psychology and neuroscience theories and findings that bear on each dimension, identifying dissenting voices when applicable. Our paper begins by describing what, our findings suggest, is the most compelling potential mechanism by which emerging phygital marketing technologies may influence consumer purchasing behavior. Specifically, via the ways they couple reduced pain of payment associated with digital payment technologies with an improved product experience made possible by ASTs and SIPs. We then go on to identify a more general framework describing consumer behavior supported by our review of the literature. Drawing on a wide range of resources, we use this framework to propose potentially fruitful dimensions of research interest and to provide preliminary explanations of how they may be influenced by emerging AST and SIP technologies. 


\section{The Psychology and Neuroscience of Purchasing Behavior}

Previous work on the consumer psychological mechanisms of phygital commerce has largely been confined to studying its impact in particular consumer markets. For example, Lawry investigates the implementation of phygital communication in the luxury segment, finding that, compared with purely digital means, it leads to greater statusseeking motivations and increased demand overall [16]. Other research has found that the multi-sensory capabilities inherent in phygital consumption make it uniquely placed to enhance happiness and consumer well-being within the fashion industry [17]. As of yet, however, a robust, industry independent account explaining phygital marketing's underlying power and appeal has not been developed. Through review and integration of relevant literatures addressing topics in consumer psychology and neuroscience, we begin developing such an account here.

While direct investigation into the psychological and neuroscientific underpinnings of phygital environments and transactions is limited, our review of the literature provides reason to believe that these decision-making processes are significantly altered in the phygital environment relative to both purely physical and purely digital alternatives. Our research suggests that one of the most promising avenues by which this transformation occurs is via the impact of phygital technologies on two primary elements in any consumer decision: the product experience prior to purchase, and the purchase experience itself. Researchers have found that consumer decisions about whether or not to complete a purchase can be predicted with considerable accuracy based on our knowledge of these two components in any given case [16,18-21].

In particular, investigations using implicit neuroimaging tools such as fMRI $[15,22]$ and EEG [23,24] have found that these subjective consumer attitudes towards product and payment value are predictive of purchase behavior. Specifically, this previous work indicates that purchase intention can be gleaned by examining the difference in evoked activity between two sets of regions in the brain: the nucleus accumbens, associated with subjective pleasure $[25,26]$, and the insular cortex, previously linked with unpleasant emotions such as disgust [27] and pain [28].

In order to illustrate the unique benefits and challenges associated with the phygital consumption environment, our review of the consumer psychology and neuroscience literature suggests we must first consider how the move from conventional in-person to digital exchange generates pressure on our evolved characteristics. Specifically, the move to digital can involve a reduction in the anticipatory pleasures and product attachments forged through in-person engagement along with a reduction in the "pain of payment" through introduction of digital methods [29].

One compelling way to view this set of findings is through an evolutionary perspective, which treats the brain as a complex processing system forged from the evolutionary pressures of a pre-modern society [30,31]. The environment within which our brains evolved over the course of millennia to become the decision-making apparatuses they are today is categorically different from the modern world [32-34]. This means that the cognitive tools we use to make everyday consumption decisions originally evolved for very different purposes $[35,36]$. Furthermore, as one would expect, the digital consumer environment poses even greater challenges than more conventional transaction models for our evolved systems $[37,38]$.

A primary factor driving this deviation from our evolutionary origins is that such exchanges lack the concrete tangibility of those involving physical goods [38,39]. Until very recently, human transactions have primarily involved the direct, in-person exchange of physical items. As we continue to abandon physical currency in favor of virtual alternatives, the consequences of this shift require further study from the standpoint of evolutionary psychology [40]. However, it is not unreasonable to suppose that the virtualization of assets will lead to unanticipated behaviors and outcomes, given the distance of that state-of-affairs from the conditions under which humans evolved. 
Bolstered by these perspectives, we propose a theoretical framework for understanding retail purchasing behavior that focuses on two dynamics of every consumer transaction: the consumer's product experience prior to purchase and the anticipated pain associated with payment (i.e., the "pain of paying"). Drawing on established findings in the psychology and neuroscience of consumer behavior, this framework helps to explain how and why phygital experiences can often empower marketers to move beyond the limitations posed by purely digital exchange to leverage the human attraction to in-person product experiences for the purpose of selling.

\subsection{Product Experiences}

The first of the two major dimensions involved in the consumer purchasing experience relates to the product experience preceding such decisions. There are two main dimensions to such evaluations: the appeal of the product itself for any given consumer and the sense of attachment to the product, generated by having interacted with it in anticipation of purchase. The former can certainly be affected by how the product is presented for consideration to consumers: the appeal of a product itself will depend on how well its features are showcased through its mode of presentation [41,42]. However, our primary focus here is not on the effective illustration of product attributes, but on how consumers' physical as opposed to digital interactions with a product will tend to promote a more powerful sense of connection or ownership over it that can affect their likelihood of purchasing it.

\subsubsection{Physical Interaction and Product Attachment}

The story begins with the rapidity and depth of attachment to goods consumers can experience upon physically handling them. Previous work has found that when consumers physically interact with products, it leads to deeper emotional connections with and attachments to them. Loss aversion [43] and the heightened attention to positive features of the goods that accompany this reframing increase their perceived value, making people more reluctant to exchange such goods for money or substitutes [44-47]. This has sometimes been framed as an extension of the endowment effect, by which individuals tend to attach greater value to goods they already own than the value they would place on the same goods if they did not own them [47].

Neuroscientific investigations into the endowment effect have found that it acts on the classic network for pleasure and pain described earlier, whereby purchase intent can be predicted by examining the differential neural activity in the nucleus accumbens (associated with subjective pleasure) and the insular cortex (associated with subjective pain) $[15,48]$.

Belk [49] and others have argued that ownership of consumer goods fulfills a deep human need to exercise autonomy within our environment and can serve as a signal to others of our social values, attributes, and affiliations [37,50,51]. This identification of self-concept with objects is connected with the phenomenon of "psychological ownership", which is defined as a significant emotional attachment between the consumer and the product [52]. Previous research has found that these emotional attachments often stem from the psychological "transference" to the consumer of positive attributes associated with the good, enhancing its contribution to consumer self-image and the degree to which it is valued [53-56]. Many have argued that psychological ownership confers benefits for both firm and consumer [44,45,47], and forges self-brand bonds $[51,57,58]$.

This effect is reflected in consumers' relative preferences: consumers show a marked preference for physical goods and are willing to pay less for digital goods than they are for their physical analogs $[59,60]$. Similarly, while consumers are willing to pay more to purchase than to rent many "utilitarian" physical goods (e.g., a hardcover textbook), they are not willing to pay more to purchase than rent similar digital goods $[59,61]$.

Recent work has also found that a sense of psychological ownership can be engendered for service-based products that do not entail ownership of a physical good [52]. Furthermore, research suggests that, when present, these feelings of ownership not only 
generate brand attachments, but result in higher evaluations of the user experience. For example, Fritze et al. find that those who feel greater psychological ownership attachments to branded car sharing services such as Uber or Lyft more frequently book cars from that service [62]. The same is true with respect to music streaming platforms, where users who hold a greater sense of ownership over their service memberships reported using it more often each week [63].

These findings have important implications for phygital approaches to marketing many access-based products, such as streaming services or product offerings, in the sharing economy. In fact, there is good reason to believe phygital product experiences will tend to enhance feelings of psychological ownership among users, as previous work has found that strong feelings of psychological ownership can be engendered through physically interacting with a product $[47,64]$. These effects are generally absent from the digital purchasing experience, as users are limited to two-dimensional visual representations or text-based product descriptions prior to purchase. The advent of virtual and augmented reality technologies offers the chance to transcend these limitations by effectively simulating the experience of actually handling or interacting with a product in immediate physical space.

\subsubsection{Digital Choice Architectures and Product Attachments}

Beyond the immediate effects of handling products (or simulated representations of products) there is reason to believe that, in certain cases, the addition of digital technologies to the consumer experience can also enhance feelings of attachment. Jai et al. find that digital interactions that are more interactive lead to greater consumer demand and increased engagement of neural mechanisms associated with product evaluation [65]. In addition, many phygital product experiences employ a digital choice architecture, allowing the consumer to customize the product or sort through many more items than would otherwise be possible in a strictly physical interface limited by physical constraints such as shelf space. These increases in consumer choice can galvanize consumer attachments to the good through engendering a stronger sense of control over it $[66,67]$.

Deeper connection can also be fostered through personalization [52]. Several retail stores have tested phygital tactics for deeper personalization. For example, at Walgreens retail locations in Manhattan, the company is piloting their "smart coolers" [68]. When consumers approach these coolers, they are promptly "scanned" by facial recognition technology. Based on their age, gender, and other demographic features, the coolers then recommend personalized drink options for them.

Likewise, flagship locations of The Container Store provide consumers with a digital interface that allows users to sift through hundreds of potential material combinations and to build and purchase these custom models on the spot [69]. Similar interactive tools have been employed at designated Levi's stores for custom made jeans [70].

In general, using digital technologies to facilitate product customization gives consumers a greater sense that they played a role in creating it. Previous research describes a so-called "IKEA Effect": consumers enjoy a product more when they build it themselves [71]. The IKEA effect generalizes to many different creation scenarios, including food production [72,73]. The preference for self-generated goods persists among consumers when comparing preferences for their own, poorly crafted creations against higher quality versions created by a specialist. For example, when asked to create an origami frog and given the choice of choosing to keep it or one that had been created by an origami expert, participants in an experiment from Norton et al. reliably preferred the one they had created despite rating the latter as being better constructed [71].

The IKEA Effect is not relegated to purely physical creations, but has also been found to hold for online customization of products [74]. Such findings may help explain the rising popularity of customizable products in the consumer world, such as NIKE By You (custom made shoes), eShakti (customizable outerwear clothes), or Prose (customized shampoo). 
These findings suggest that digital choice architectures that increase consumer choice by increasing the number of product options and customizability can promote consumer feelings of psychological ownership and attachment. However, it should be noted that, under some circumstances, customer choice has also been demonstrated to decrease perceptions of product value $[75,76]$. These negative effects are more likely when the consumer decision involves a high degree of cognitive complexity, such as in cases where there are many variables on which products can be compared or where many products exhibit similar qualities on a range of characteristics [77-79]. Similar effects have been found when attention is drawn to a range of alternative options to increase their salience within a given decision scenario $[80,81]$.

\subsection{Payment Experience}

A second primary dimension contributing to the power of deploying phygital strategies to influence the consumer's product purchasing experience is the payment process. Whereas interaction with products and anticipation of ownership are generally pleasurable experiences, paying for goods is generally associated with psychological pain and discomfort. This is captured in brain-based studies, which indicate that the contemplation and exercise of payment for consumer products activates the insula, a part of the brain connected with anticipation of physical pain and negative arousal more generally $[15,65]$. Naturally, the degree of pain scales with cost, with large purchases tending to generate greater pain than smaller ones. As pain of payment increases, the likelihood that a purchase will be completed tends to diminish [15].

\subsubsection{Effects of Payment Method Abstraction/Unfamiliarity}

Consistent with an evolutionary conception of consumer behavior, the most concrete forms of payment are experienced as being the most "real", and therefore the most psychologically painful. The most concrete form of payment available to modern-day consumers is the physical exchange of cash for goods. From there, the pain of paying decreases as payment systems become more abstracted from the practice of direct physical exchange. This reduction in the pain response associated with paying is correlated with an increased likelihood that consumers will be willing to pay a given price for goods [82].

For example, in an experimental study, Mazar et al. find that the detection of subjective pain experiences within the insular cortex is directly tied to payment aversion [83]. In a separate study within the same paper, they find further support for this idea by directly manipulating affective pain perceptions through conceptual priming, finding that it reduced participants' willingness to pay.

Other research suggests that consumers tend to experience less pain or discomfort and are more willing to pay a given price for goods when the purchase is made with a credit card [84-86] or when spending currencies with no physical analogue, such as airline points rather than cash [87]. Consistent with these findings, gamblers are much looser with their money using poker chips (more abstract) rather than hard cash (more concrete) [88].

In general, paying by card has also been found to affect the perception of cost, making it less salient and painful, and consumers generally spend significantly more when shopping with a credit card than when using cash [89]. The mechanism behind these differences is readily apparent on an intuitive level: using a card to pay for goods simply does not feel as real as parting with cash.

In recent work, consumers have been found to spend even more freely and experience less subjective pain when using NFC payment technologies built into mobile phones and smart watches rather than credit cards [90]. In such cases, the same general pattern appears to hold: the more abstract and unfamiliar the payment system, the less real the payment feels, and the more freely the consumer spends.

This is a crucial observation for phygital consumer experiences like the ones we are examining here, which involve pairing digital payments with a physical product experience. As we have seen, the classic example of seamless digital payments within a largely physical 
environment is Amazon Go. Similar payment systems have been piloted by Chinese locations of Kentucky Fried Chicken, which allow users to pay for their meals through facial recognition [91]. These payment structures take us a step beyond even the ease of NFC payments described above, as no conscious attention to the payment process is required at all. When the payment process is almost entirely detached from any kind of physical act, its abstraction from the real-world exchange of physical assets will loom large.

It is worth noting that, on some level, all comparisons of value involved in the exchange of goods are, in effect, symbolic. Even "cold hard cash" is an artifice, a representation for spending power with no direct intrinsic value. Therefore, these effects may not be solely attributable to abstraction, but also to (lack of) familiarity with the payment system, meaning these findings may change over time. Nonetheless, the fact remains that, at least for the time being, these new symbolic representations of actual currency are generally valued less than the immediate currency itself.

\subsubsection{Effects of Delayed Payment/Payment over Time}

Alongside reductions in the perceived costs of payment, digital payment options also allow for greater abstraction by separating the decision to pay away from the feeling of having paid. For example, consumers are more likely to agree to a payment in the future, reflecting what psychologists call the intention-action gap. In a clever demonstration of this gap, Loewenstein et al. asked undergraduate participants if for ten dollars they would be willing to dance to Rick James' hit song "Super Freak" in front of all their classmates in the school quad [92]. When asked to start dancing right then and there, few students took him up on his offer. However, many more agreed if the dance was scheduled to take place several days later. Perhaps unsurprisingly, most of those students who did agree to perform in the future then went on to renege on the day of the event.

This is an entirely relatable finding: people agree to do things in the future that would otherwise be unthinkable in the present moment. "Buy now, pay later" promotions dull the pain of payment by muddying up the financial exchange of a purchase, such that consumers "forgo" pain of payment [29], experiencing the burden when payments begin to come due and not in the moment, when the payment decision is made. Digital payment has led to a proliferation of such arrangements by making them far easier to facilitate.

For example, Kamleitner and Erki employ a longitudinal study to investigate the impact of payment method on psychological ownership over time [93]. They find that cash payers report higher levels of immediate psychological ownership than card payers, a difference which diminishes over time. Other research has found that paying with credit cards as opposed to cash is associated with seeing products in a more positive light overall. In sum, as payments become more abstract, consumers spend more freely, become less psychologically impacted by them, and feel more attached to the goods they buy.

\subsection{The Phygital Advantage}

This review of the literatures on the psychology and neuroscience of the product experience and pain of paying provides the necessary context on which to build a compelling theory of phygital marketing's potentially significant impact. It suggests that the power of phygital marketing may stem specifically from the relationship involved between the cultivation of elevated product attachment through direct product experience and reduced pain of payment due to digital payment technologies. As we have seen, the prospect is that the integration of these media can provide the best of both worlds for consumers: the ease and seamlessness of digital payment, with the tangibility and personability of physical product experiences.

While general excitement about these developments is warranted, the sheer diversity of ways in which physical and digital components may be integrated makes it difficult to judge phygital as a monolithic category. Without narrowing in on specific combinations of product experiences and payment methods, it will be difficult to evaluate questions about its impact on the consumer experience, purchase likelihood, brand perception, etc. For 
these reasons, we have committed to focusing on the pair of ideal types described above, which represent a large proportion of possible cases. In both cases, the reduced transaction costs of digital purchasing are combined with a (real or simulated) in-person experience, compensating for the weaknesses of either model.

By combining the visceral connection with consumer goods experienced through in-person interaction with the reduced pain of payment facilitated by digitization, phygital marketing creates an environment that will often increase the probability of purchase for consumer products.

\section{Additional Dimensions of Phygital Impact: A General Framework}

In the remainder of the paper, we situate the dynamics of phygital marketing that have been our focus so far within the larger decision-making process undertaken by retail consumers at the point of purchase, highlighting important contributions to this literature as we proceed. As we have seen, the decision-calculus undertaken by such customers involves consequentialist calculation of the anticipated "gains and pains" of buying goods. While our attention has so far been focused on the relationship between consumer product attachment and the general phenomenon of "pain of paying", we survey work on several additional considerations that enter into that broader process here. Taken together, these considerations culminate in a more general theoretical framework grounded on a review of primary and secondary research findings from consumer psychology and consumer neuroscience to explain the potential power of phygital marketing experiences, account for their unique value, and provide a platform for future research. The elements of this framework are illustrated in Figure 1.

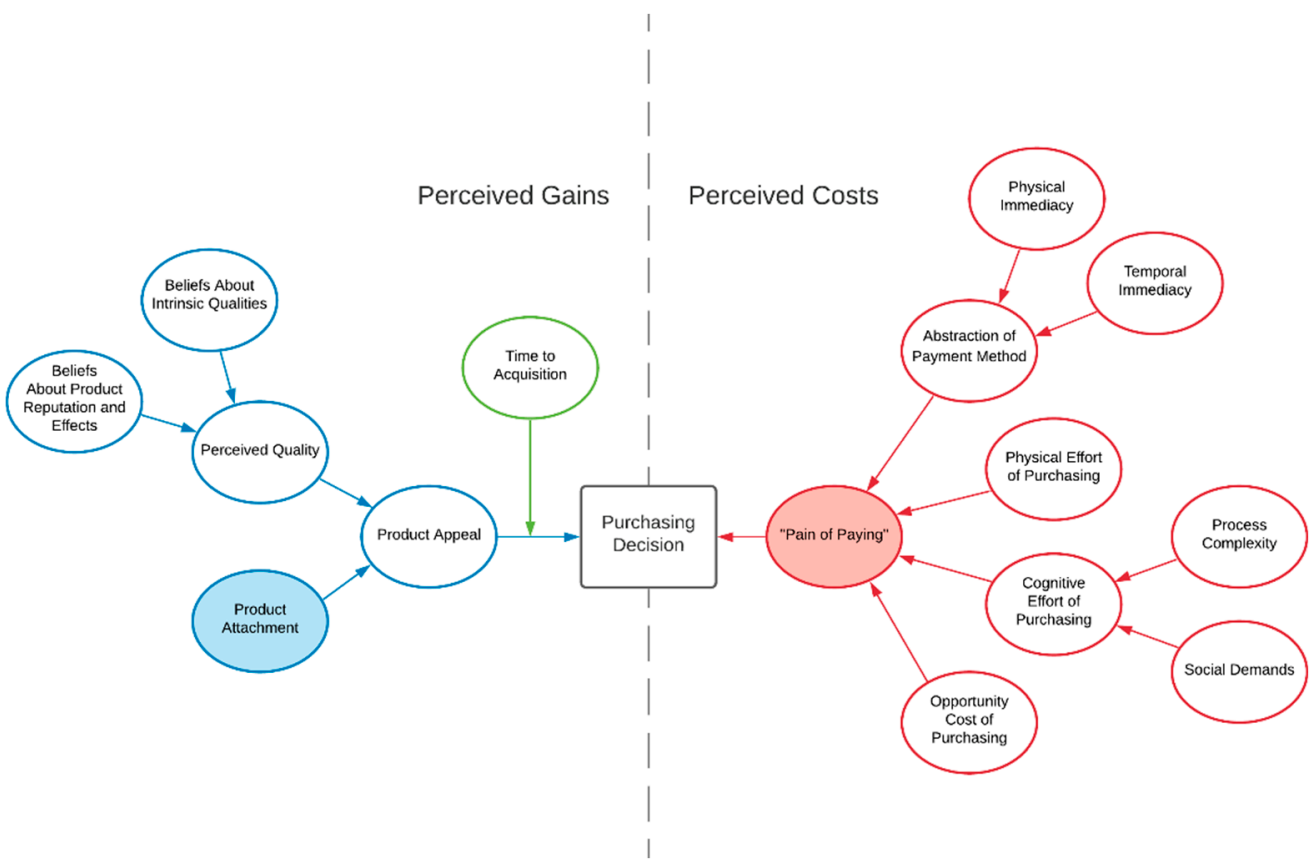

Figure 1. Gain/Loss Calculation Factors.

The relevance of phygital marketing on these different dimensions will need to be explored in order to understand their importance relative to the theoretical mechanisms we have described here. Furthermore, although our review of relevant literatures suggests that increased product attachment may be the primary vehicle driving increased purchase likelihood across sectors, identifying the effects of phygital marketing on these other dimensions will be crucial if we are to gain a finer-grained understanding of when and how phygital marketing is most effectively implemented within different retail purchasing environments. We discuss possible implications of emerging phygital marketing technologies indicated 
by existing research for most of the dimensions included below, raising possible ways that they might be used to enhance perceived gains or reduce perceived pain of payment.

\subsection{Anticipated Costs ("Pain of Paying")}

We begin with a more fine-grained analysis of the elements contributing to consumer calculations regarding the anticipated costs of buying goods and of phygital's potential impact on them, when applicable. As we have seen, these costs are described in terms of the "pain of paying" within dominant psychology and neuroscience literatures on consumer behavior. Existing research suggests that four main elements (captured on the right hand side of Figure 1) contribute to such calculations, each of which may be comprised of multiple dimensions: abstraction of payment method, physical effort of purchasing, cognitive effort of purchasing, and opportunity cost of purchasing. A description of each dimension along with lists of potential measurement variables, key questions, and relevant resources are provided in Table 1.

\subsubsection{Abstraction of Payment Method}

We start with the abstraction of payment methods. As we have already discussed, consumers tend to be more willing to spend money as the payment method becomes increasingly less concrete and direct. There are two main ways this abstraction from the physical reality of exchange can occur.

First, differences in the "physical immediacy" of payment-i.e., deviations from the physical exchange of cash-will have important consequences. As we have seen, even the simple move from paying with cash to paying with a debit card results, on average, in less reported pain of payment and increased spending [94]. Soetevent deploys a field experiment involving charitable giving to further examine the implications of debit rather than cash payments. He finds that respondents who are only given the option to pay with cash are far more likely to participate, but pay far less than those in the "debit-only" condition or those who pay with debit despite being given the choice to pay with either method [95].

Furthermore, shifts in the "temporal immediacy" of payment can have similar effects. Temporal immediacy is dictated by whether there is a time lag between receipt of a retail good and payment for that good. There are two main ways this can occur.

First, when purchasers use credit or otherwise receive financing for the payment of a good, it involves an increase in the duration of payment and reduction in the raw amount paid at any given time. Researchers have repeatedly observed that consumers who predominantly pay with credit cards spend more than those who pay with more direct payment methods $[88,96]$, though Hafalir and Loewenstein find that this effect is predominantly confined to "convenience users" who do not carry debt [84].

Second, it can occur when something is paid for in advance or when payment does not occur until some time after receipt of a good. Research suggests that one explanation for this phenomenon involves time discounting - that is, the utility discounting of future gains and losses relative to their present value. The literature on time discounting is huge and nuanced, unearthing a range of significant findings. A range of experimental studies has found that gains are discounted at a higher rate than losses, meaning that individuals are often more willing to put off future payments than future gains [97-99]. Furthermore, research suggests that "small" outcomes involving relatively little value are discounted more than "large" ones [97,98,100-103]. Finally, Prelec and Loewenstein demonstrate the role played by mental "coupling" in influencing such outcomes. Specifically, they show that the pain of paying can often be minimized when, psychologically, "consumption is decoupled from payments (so that consumption does not evoke thoughts about payment)" [89].

In either case, the delaying of payment can impact the perceived pain with which it is associated, and the emergence of digital payment methods has multiplied the possibilities for such abstraction from physical exchange. 


\subsubsection{Opportunity Cost of Purchasing}

The amount of time it takes to complete a purchase can also contribute to increasing pain of payment. For example, Gupta et al. find that consumers will regularly switch retail channels from in-person to online/digital (or vice-versa) in response to the increased pain of payment associated with waiting for a long period of time in order to complete their transactions [104]. Furthermore, they express strong desires grounded in a utilitarian consumer ethos to see the implementation of technologies that will "help them find products faster ... and undertake a streamlined shopping experience, which reflects their utilitarian, extrinsic shopping motivations" $[105,106]$. This is undoubtedly more of a problem attending in-person shopping experiences, where the time spent going to the store and physically shopping could be spent in other pursuits, a finding supported by survey respondents, 70 percent of whom express dissatisfaction with the speed of the physical retail experience [105]. The automated sensing technologies empowering cashierless payment options like Amazon Go have the potential to significantly reduce pain of payment in this respect by reducing or eliminating in-person wait times at the point of purchase.

\subsubsection{Physical Effort of Purchasing}

As in the case of opportunity cost, when the amount of physical effort involved in completing a purchase increases, so too will the perceived pain of payment. For example, it takes effort to get up and go to a store to purchase something. If it can be bought and shipped from the comfort of one's home, it will result in reduced pain of payment. So-called "utilitarian" shopper types place particular importance on this dimension, in large part calculating the value of their shopping experiences in terms of its efficiency, including the ratio of shopping "effort" to output [106-108]. Other factors, including the hedonic pleasures of the shopping experience [109-111] and (as we have seen) product attachment forged through such in-person experiences may alter the calculus, but will do so on different dimensions.

Phygital strategies involving the use of AR and VR to simulate the in-person shopping experience offer the prospect of reducing anticipated pain of payment associated with the physical strain of shopping. At the same time, they minimize deficiencies in terms of product experience and interactivity that accompany most current approaches to digital marketing and "at-home shopping".

\subsubsection{Cognitive Effort of Purchasing}

The degree of cognitive "strain" required to complete a purchase will also contribute to increasing pain of payment and can take two forms.

First, the complexity of the payment process itself can contribute to such a negative emotional response. Process complexity can involve a range of different factors depending on the context, and many consumers anticipate that the adoption of new payment technologies can lead to hassles and headaches [6]. If, for example, there are many steps to complete, or if the consumer must enter their credit card number many times or sign many documents before completing their purchase, research suggests we can confidently assume that it leads to increased pain of payment. In a large, survey-based study of consumer preferences when it comes to making online purchases, Burke finds a strong preference across product categories for systems that save billing and shipping information and facilitate one-click ordering [106]. Similar findings abound in the literature on shopper "types", with those holding utilitarian tendencies placing heavy emphasis on the value of technological ease of payment [6]. The degree to which these preferences are properly accounted for within the purchasing experience will affect consumer decision-making both prior to and at the time and point of purchase. 
Table 1. Anticipated Costs ("Pain of Paying").

\begin{tabular}{|c|c|c|c|c|}
\hline Dimension & Description & $\begin{array}{l}\text { Measurement } \\
\text { Variables }\end{array}$ & Key Questions & Related Research \\
\hline \multirow[t]{2}{*}{$\begin{array}{l}\text { Abstraction of } \\
\text { payment } \\
\text { method }\end{array}$} & $\begin{array}{l}\text { Does the purchase take } \\
\text { place through a direct } \\
\text { exchange of currency for } \\
\text { goods, or are there } \\
\text { vehicles for indirect } \\
\text { transacting involved? }\end{array}$ & $\begin{array}{l}\text { Physical immediacy } \\
\text { (e.g., cash vs. debit } \\
\text { payment) }\end{array}$ & $\begin{array}{l}\text { How does the physical means } \\
\text { of transacting affect purchase } \\
\text { likelihood and associated brain } \\
\text { function? }\end{array}$ & [94-96] \\
\hline & & $\begin{array}{l}\text { Temporal immediacy } \\
\text { (e.g., immediate } \\
\text { cash/debit vs. } \\
\text { credit/financing } \\
\text { payment; paying in } \\
\text { advance vs. paying } \\
\text { upon receipt of good or } \\
\text { service) }\end{array}$ & $\begin{array}{l}\text { How does the temporal } \\
\text { separation of purchase and } \\
\text { payment (i.e., the degree of } \\
\text { "coupling") during the process } \\
\text { of transaction affect purchase } \\
\text { likelihood and associated brain } \\
\text { function? }\end{array}$ & $\begin{array}{l}{[84,87,89,96-} \\
103,105,106]\end{array}$ \\
\hline $\begin{array}{l}\text { Opportunity } \\
\text { cost of } \\
\text { purchasing }\end{array}$ & $\begin{array}{l}\text { The amount of time it } \\
\text { takes to complete a } \\
\text { purchase (e.g., do } \\
\text { customers have to wait in } \\
\text { a real or virtual line?) }\end{array}$ & $\begin{array}{l}\text { Average time to } \\
\text { completion of purchase }\end{array}$ & $\begin{array}{l}\text { How does the real or } \\
\text { anticipated amount of time it } \\
\text { will take to complete an initial } \\
\text { purchase affect purchase } \\
\text { likelihood and associated brain } \\
\text { function? }\end{array}$ & {$[104,105,109,111-113]$} \\
\hline $\begin{array}{l}\text { Physical effort } \\
\text { of purchasing }\end{array}$ & $\begin{array}{l}\text { The degree of physical } \\
\text { "strain" required to } \\
\text { complete the purchase } \\
\text { (e.g., does it take physical } \\
\text { exertion to search for } \\
\text { products or present them } \\
\text { for purchase?) }\end{array}$ & $\begin{array}{l}\text { Time spent engaging in } \\
\text { physical vs. virtual } \\
\text { product search, extent } \\
\text { of physical labor } \\
\text { involved in act of } \\
\text { purchasing }\end{array}$ & $\begin{array}{l}\text { How does the real or } \\
\text { anticipated amount of physical } \\
\text { effort it will take to complete a } \\
\text { purchase affect purchase } \\
\text { likelihood and associated brain } \\
\text { function? }\end{array}$ & {$[106,107,109,110]$} \\
\hline $\begin{array}{l}\text { Cognitive effort } \\
\text { of purchasing }\end{array}$ & $\begin{array}{l}\text { The degree of cognitive } \\
\text { "strain" required to } \\
\text { complete the purchase }\end{array}$ & Process complexity & $\begin{array}{l}\text { How does the complication } \\
\text { and complexity of the } \\
\text { purchasing process affect } \\
\text { purchase likelihood and } \\
\text { associated brain function? } \\
\text { How does the amount of social } \\
\text { interaction involved in the } \\
\text { purchasing process affect } \\
\text { purchase likelihood and } \\
\text { associated brain function? }\end{array}$ & {$[6,114-116]$} \\
\hline
\end{tabular}

Second, social demands such as the requirement to speak to a cashier, deal with a sales representative, or ask for help may in some cases increase pain of payment. Social interaction is more challenging and "painful" for some individuals than others, and contextual factors may also affect the amount of pain consumers experience in the purchasing environment. Meuter et al. report a strong desire among many consumers to "create a shopping experience without the interference of sales staff," in many cases preferring a direct replacement of service staff with technological alternatives $[115,116]$. Similar findings are presented in an extensive analysis conducted by Riegger et al., with a subset of subjects reporting their distaste for "babbling" sales representatives who "bustle around" them but lack the focused, streamlined purposiveness of modern search technologies [6]. As such, the increasing popularity of self-checkout at major retailers such as Walmart, Target, and CVS may be partly explained by the reticence of consumers to engage in the social niceties required in the transaction environment. Further research will be required and the relative popularity of self-checkout varies widely depending on a number of contextual factors that make it difficult to generalize. Nonetheless, it stands to reason that, for at least some 
consumers, the social demands of purchasing involve increased pain of payment that may be diminished through digital exchange.

Interestingly, the creation of interactive robotic or AR assistants to aid in the in-person and online shopping experience may help to avoid some of the complications involved in removing human individuals from the customer service experience. The development of autonomous digital personas capable of helping customers but with whom they will feel less social pressure or obligation could, for some customers, reduce the pains and anxieties associated with the retail shopping experience while availing them of contact with an approachable "human-like" assistant. Trials of these technologies using life-like robots in Japanese retail settings have been received with enthusiasm, particularly among older shoppers who often feel more comfortable engaging with AI robots who have simulated human characteristics than others [117].

\subsection{Anticipated Gains}

At least three dimensions (captured on the left hand side of Figure 1) may predict the anticipation of gains among retail consumers at the point of purchase. Two of the three-perceived quality and product attachment-fall into the broad category of "product appeal", while a third, time to acquisition, will often mediate product appeal through mechanisms like time discounting. A description of each dimension along with lists of potential measurement variables, key questions, and relevant resources are provided in Table 2.

Table 2. Anticipated Gains.

\begin{tabular}{|c|c|c|c|c|}
\hline Dimension & Description & Measurement Variables & Key Questions & $\begin{array}{l}\text { Related } \\
\text { Research }\end{array}$ \\
\hline \multirow[t]{2}{*}{$\begin{array}{c}\text { Product appeal } \\
\text { (perceived } \\
\text { quality) }\end{array}$} & \multirow[t]{2}{*}{$\begin{array}{l}\text { Consumer beliefs about a } \\
\text { product's level of quality }\end{array}$} & $\begin{array}{l}\text { Consumer beliefs about a } \\
\text { product's intrinsic qualities } \\
\text { (e.g., "intrinsic quality" } \\
\text { dimensions might include } \\
\text { perceived attractiveness, } \\
\text { durability, functionality, etc.) }\end{array}$ & $\begin{array}{l}\text { When, for whom, for what types } \\
\text { of products, and to what extent } \\
\text { do consumer beliefs about a } \\
\text { product's "intrinsic qualities" } \\
\text { affect purchase likelihood? }\end{array}$ & [118-124] \\
\hline & & $\begin{array}{l}\text { Consumer beliefs about } \\
\text { product reputation and } \\
\text { associated effects (e.g., what } \\
\text { do others think about the } \\
\text { product and what will } \\
\text { owning the product lead } \\
\text { others to think about me? }\end{array}$ & $\begin{array}{l}\text { When, for whom, for what types } \\
\text { of products, and to what extent } \\
\text { do consumer beliefs about } \\
\text { product and/or brand } \\
\text { reputation affect purchase } \\
\text { likelihood? }\end{array}$ & [122-124] \\
\hline $\begin{array}{l}\text { Product appeal } \\
\text { (product } \\
\text { attachment) }\end{array}$ & $\begin{array}{l}\text { The extent to which a } \\
\text { given means of } \\
\text { showcasing the product } \\
\text { provides consumers with } \\
\text { experiences that generate } \\
\text { product attachment or a } \\
\text { sense of "psychological } \\
\text { ownership" }\end{array}$ & $\begin{array}{l}\text { Consumer attachment levels } \\
\text { as evidenced by, e.g., } \\
\text { self-report, willingness to } \\
\text { exchange for a product of } \\
\text { equal perceived quality, } \\
\text { increased valuation relative } \\
\text { to pre-exposure levels }\end{array}$ & $\begin{array}{l}\text { For a given level of perceived } \\
\text { product quality, how (if at all) do } \\
\text { different types of pre-purchase } \\
\text { "exposure" to the product (e.g., } \\
\text { image vs. video vs. AR/VR } \\
\text { interaction vs. first-person use) } \\
\text { affect product attachment and } \\
\text { purchase likelihood? How are } \\
\text { these effects mediated by } \\
\text { product and customer type } \\
\text { and/or time to acquisition? }\end{array}$ & $\begin{array}{c}{[15,47,105,} \\
125-127]\end{array}$ \\
\hline $\begin{array}{l}\text { Time to } \\
\text { acquisition }\end{array}$ & $\begin{array}{l}\text { The length of time a } \\
\text { customer must wait } \\
\text { between completing the } \\
\text { transaction and receiving } \\
\text { the good or service }\end{array}$ & $\begin{array}{l}\text { Consumer beliefs about time } \\
\text { to product acquisition after } \\
\text { completion of initial } \\
\text { transaction }\end{array}$ & $\begin{array}{l}\text { How does the anticipated time } \\
\text { to product acquisition affect } \\
\text { purchase likelihood? How are } \\
\text { these effects mediated by } \\
\text { product and customer type? }\end{array}$ & [128-130] \\
\hline
\end{tabular}




\subsubsection{Product Appeal (Perceived Quality)}

The first, and in many cases most important, dimension affecting consumers' anticipated gains at the point of purchase is the perceived quality of the product itself. Though there are potentially many more ways the research on this category might be broken down, we have settled on two main subdimensions here.

The first, "consumer beliefs about a product's intrinsic qualities" reflects the specific virtues of the product itself, including elements such as its perceived attractiveness and style, durability, functionality, etc. The "intrinsic qualities" of different products will clearly be subject to dispute and their measurement will be heavily dependent on the nature of the product. Nonetheless, it is important to differentiate the specific qualities of products and their impact on the likelihood a consumer will purchase them from the attachment generated through their presentation via marketing appeals and consumer exposure. For example, Sun et al. distinguish four key features of product quality for consumers in the fashion industry. They include, in descending order of significance: style, durability, color, and sustainability [118]. Multiple studies identify product quality as a competitive advantage in the marketing of manufactured goods [118-121], while Handfield et al. find that improvements in product quality over time are increasingly necessary as globalization drives a growing consumer demand for quality products [119].

In addition to the "consumer attachment" effects described above, phygital marketing involving simulated in-person experiences holds potential to influence consumer judgments about product quality. Assuming AR/VR technologies are sufficiently robust, they may be deployed to help companies expose the specific qualities of a product and to differentiate their product from those of competitors. For example, Wedel et al. argue that these technologies can play a key role in helping to contextualize the real-world use of products by "showing it being used in a (desirable) virtual context" [116]. As we have seen, there is reason to believe that direct interaction with realistic product models can garner more interest and will often generate greater product enthusiasm than exposure to conventional documents, images, or videos. Furthermore, the ability to directly inspect products rather than have them shown to the customer in ways that cast them in the best possible light to benefit the seller can empower consumer confidence in their purchases. Alcaniz et al. note that this effect can be empowered by the "multiple angle manipulation" of products availed by VR and AR, relative to traditional two-dimensional marketing materials [108].

The second subdimension of perceived quality is "consumer beliefs about product reputation and associated effects." In many cases, the intrinsic qualities of a product may impact its reputation. However, this category is solely focused on measuring what others think about the product and what owning the product will lead them to think about the owner. The importance of brand reputation is well-established within the marketing literature, though these effects may be more or less acute depending on the product category. For example, although researchers find that consumers exhibit diminishing price sensitivity as brand reputation increases, the magnitude of these effects is highly dependent on product category [122]. Furthermore, across categories and countries brand credibility has been found to have a particular impact on those who place a high value on ingroup membership ("collectivist consumers") and those with a particular aversion to uncertainty [123]. In a particularly noteworthy study by Rindova et al., researchers find that, other things being equal, brand prominence, as measured by brand and product affiliation with favorable media coverage and celebrity endorsement, "contributes significantly to the price premium associated with having a favorable reputation" [124]. One way that phygital marketing may enhance product appeal on this dimension is via the ability of consumers to share product experiences with others in an online setting. For example, sharing the virtual first-person experience of a product with others via digital communications or social media from the comfort of their homes or while on the go has the potential to attract considerable product interest. To the extent these experiences proliferate and leave favorable impressions on those exposed to them, they will provide one more tool in the marketer's arsenal by which to enhance product reputation. 


\subsubsection{Product Appeal (Product Attachment)}

Our review of relevant literatures has suggested that product attachment is primarily a product of exposure to good through marketing and other experiences prior to purchase. Specifically, it is determined by the extent to which a given means of showcasing the product provides consumers with experiences that generate product attachment or a sense of "psychological ownership". These factors might be measured in a range of ways, including self-reported attachment levels, the willingness of customers to exchange the product for a product of equal perceived quality, and/or the extent to which their valuation of the product increases relative to pre-exposure levels. Much of this paper has already been dedicated to reviewing how phygital marketing impacts product attachment levels, meaning no further discussion of such potentials is required here.

\subsubsection{Time to Acquisition}

Finally, the length of time a customer must wait between completing a transaction and receiving the product will undoubtedly affect the anticipated gains from purchasing it. Due in considerable part to many of the "time discounting" factors described above [101,106], consumer beliefs about the time it will take to receive a product after completion of the initial transaction will often mediate the overall appeal of the product, and long wait times can in some cases lead to preferences for one product over another. Dedicated studies confirm these suspicions. In survey-based studies by Ma [128] and Cao et al. [129], researchers find that shipping time has a significant impact on consumer perception of products and customer satisfaction. In another study, Huang et al. find that, in cases where retailers specify a threshold purchase amount that must be surpassed in order to receive free shipping, consumer's willingness to pay is significantly impacted by the timeliness of shipment [130]. The introduction of phygital technologies may moderate these anxieties in some cases in at least two possible ways.

First, the proliferation of digital sensing technologies empowering cashierless purchasing during in-person shopping may ultimately help preserve the viability of brickand-mortar outlets through their impact on overhead costs at these locations. This may in some cases help reduce the time to acquisition of purchased products, at least in cases where maintaining in-store inventory remains a priority or shipping networks facilitate more rapid movement of goods to in-store locations than to personal residences.

Second, simulated in-person product experiences may help to ease some of the anxiety associated with waiting for product arrival by providing customers with virtual exposure to the product prior to receipt. These effects will vary depending on the product and further research into them is necessary if they are to be confirmed. However, there is reason to believe that, at least in cases where part of the anxiety associated with delays between purchase and receipt relate to a lack of consumer confidence in the quality of their purchase, these technologies could help ease concerns.

\section{Conclusions}

Phygital consumer experiences provide marketers an opportunity to combine and leverage the benefits of in-person shopping with digital payment in ways that are already transforming the modern retail shopping environment. In this paper, we have conducted an expansive review of interdisciplinary literatures on the psychology and neuroscience of consumer purchasing behavior in order to explore the mechanisms that drive phygital marketing's revolutionary potential at the point of purchase. We have focused particular attention on the large corpus of work indicating that in-person or "simulated in-person" experiences can generate increased product attachment without sacrificing the reduced pain of payment associated with digital purchasing. In the latter half of the paper, we summarized the findings of our review by developing a more general framework, describing a range of consequential consumer decision-criteria and considering the implications of phygital marketing technologies on these dimensions, as well. 
Future research into the impact of phygital marketing on retail consumer decisionmaking will require more direct investigation into the effects of specific phygital interventions in different contexts. As of yet, the proliferation of phygital experiences is insufficient to support large-scale observational studies, meaning that experimental research may be the best means of trying to understand the various dynamics of these emergent strategies. We have indicated a range of key questions relating to the impact of phygital marketing on consumer behavior that require further investigation in the tables provided above.

We hope that the theoretical justifications we have discussed here for introducing phygital techniques into the digital shopping experience will help firms to understand the dynamics involved and to make better decisions about the strategic role that such methods can play in their own practice.

Author Contributions: The authors are jointly and equally responsible for the production of this article. A formal breakdown of contributions follows. Conceptualization, M.J. and R.B.; resources M.J. and R.B., writing — original draft preparation, M.J. and R.B.; writing—review and editing, M.J. and R.B. All authors have read and agreed to the published version of the manuscript.

Funding: This research received no external funding.

Conflicts of Interest: The authors declare no conflict of interest.

\section{References}

1. Cabigiosu, A. Digitalization in the Luxury Fashion Industry; Springer Science and Business Media LLC: Berlin/Heidelberg, Germany, 2020.

2. Shi, S.; Wang, Y.; Chen, X.; Zhang, Q. Conceptualization of omnichannel customer experience and its impact on shopping intention: A mixed-method approach. Int. J. Inf. Manag. 2020, 50, 325-336. [CrossRef]

3. Hollebeek, L.D.; Sprott, D.E.; Andreassen, T.W.; Costley, C.; Klaus, P.; Kuppelwieser, V.; Karahasanovic, A.; Taguchi, T.; Islam, J.U.; Rather, R.A. Customer engagement in evolving technological environments: Synopsis and guiding propositions. Eur. J. Mark. 2019, 53, 2018-2023. [CrossRef]

4. Nofal, E.; Reffat, M.; Vande Moere, A. Phygital heritage: An approach for heritage communication. Immersive Learn. In Immersive Learning Research Network; Verlag der Technischen Universität Graz: Graz, Austria, 2017; pp. 220-229.

5. Moravcikova, D.; Kliestikova, J. Brand Building with Using Phygital Marketing Communication. J. Econ. Bus. Manag. 2017, 5, 148-153. [CrossRef]

6. $\quad$ Riegger, A.-S.; Klein, J.F.; Merfeld, K.; Henkel, S. Technology-enabled personalization in retail stores: Understanding drivers and barriers. J. Bus. Res. 2021, 123, 140-155. [CrossRef]

7. Batat, W. Experiential Marketing: Consumer Behavior, Customer Experience and the 7Es; Routledge/Taylor \& Francis Group: New York, NY, USA, 2019.

8. Purcărea, T. Modern Marketing, CX, CRM, Customer Trust and Identity 2019. Available online: https://ideas.repec.org/a/hmm/ journl/v9y2019i1p42-55.html (accessed on 10 July 2021).

9. Belghiti, S.; Ochs, A.; Lemoine, J.-F.; Badot, O. The Phygital Shopping Experience: An Attempt at Conceptualization and Empirical Investigation; Springer Science and Business Media LLC: Berlin/Heidelberg, Germany, 2017; pp. 61-74.

10. Kestenbaum, R. The Impact of 3000 Amazon Go Stores Will Be Massive. Forbes 2018. Available online: https:/ /www.forbes.com/ sites/richardkestenbaum/2018/09/23/3000-amazon-go-stores-ibm-cisco-ncr-fujitsu-toshiba-oracle/?sh=73d942585147\#2cd9 567c5147 \T1 \textquoteright (accessed on 27 July 2021).

11. CB Insights. Beyond Amazon Go: The Technologies and Players Shaping Cashier-Less Retail. CB Insights 2018. Available online: https://www.cbinsights.com/research/cashierless-retail-technologies-companies-trends/ (accessed on 28 July 2021).

12. Papagiannis, H. How AR is Redefining Retail in the Pandemic. Harvard Bus Rev Digit Artic 2020. Available online: https: / / hbr.org/2020/10/how-ar-is-redefining-retail-in-the-pandemic (accessed on 28 July 2021).

13. NielsenI, Q. Augmented retail: The New Consumer Reality. 2019. Available online: https://nielseniq.com/global/en/insights/ analysis /2019/augmented-retail-the-new-consumer-reality-2/ (accessed on 28 July 2021).

14. Hackl, C.; Wolfe, S.G. Marketing New Realities: An Introduction to Virtual Reality E Augmented Reality Marketing, Branding, E Communications; Meraki Press: Kuala Lumpur, Malaysia, 2017.

15. Knutson, B.; Rick, S.; Wimmer, G.E.; Prelec, D.; Loewenstein, G. Neural Predictors of Purchases. Neuron 2007, 53, 147-156. [CrossRef]

16. Lawry, C.A. Blurring luxury: The mediating role of self-gifting in consumer acceptance of phygital shopping experiences. Int. J. Advert. 2021, 2021, 1-27. [CrossRef]

17. Armstrong, K.; Rutter, C.; Tavana, M.; Vecchi, A. Exploring the Enigma of the Happiness Construct in Phygital Fashion Experiences. Adv. Bus. Inf. Syst. Anal. 2017, 220-233. [CrossRef] 
18. Loewenstein, G.; Prelec, D. Anomalies in Intertemporal Choice: Evidence and an Interpretation. Q. J. Econ. 1992, $107,573-597$. [CrossRef]

19. Roberts, J.A.; Jones, E. Money Attitudes, Credit Card Use, and Compulsive Buying among American College Students. J. Consum. Aff. 2001, 35, 213-240. [CrossRef]

20. Thomas, M.; Desai, K.K.; Seenivasan, S. How Credit Card Payments Increase Unhealthy Food Purchases: Visceral Regulation of Vices. J. Consum. Res. 2011, 38, 126-139. [CrossRef]

21. Fortunato, V.C.R.; Giraldi, J.D.M.E.; Oliveira, J. A Review of Studies on Neuromarketing: Practical Results, Techniques, Contributions and Limitations. J. Manag. Res. 2014, 6, 201. [CrossRef]

22. Banker, S.; Dunfield, D.; Huang, A.; Prelec, D. Pain of payment and the moral tax: The neural basis of the credit card effect. ACR N. Am. Adv. 2017, 45, 514 .

23. Flores, A.; Münte, T.F.; Doñamayor, N. Event-related EEG responses to anticipation and delivery of monetary and social reward. Biol. Psychol. 2015, 109, 10-19. [CrossRef]

24. Gorka, S.M.; Phan, K.L.; Shankman, S.A. Convergence of EEG and fMRI measures of reward anticipation. Biol. Psychol. 2015, 112, 12-19. [CrossRef]

25. Lerner, T.N.; Holloway, A.L.; Seiler, J.L. Dopamine, Updated: Reward Prediction Error and Beyond. Curr. Opin. Neurobiol. 2021, 67, 123-130. [CrossRef]

26. Carlezon, W.A.J.; Thomas, M.J. Biological substrates of reward and aversion: A nucleus accumbens activity hypothesis. Neuropharmacology 2009, 56, 122-132. [CrossRef]

27. Kecinski, M.; Lusk, J.; Messer, K.D. A Neuroeconomic Investigation of Disgust in Food Purchasing Decisions; Department of Applied Economics and Statistics. Available online: http:/ / udspace.udel.edu/handle/19716/24896 (accessed on 10 September 2021).

28. Nieuwenhuys, R. The insular cortex: A review. Prog. Brain Res. 2012, 195, 123-163.

29. Huang, L.; Savary, J. Attenuating Endowment Effect With Venmo: Online Payment Systems Make It a Pleasure to Pay. ACR N. Am. Adv. 2018, 46, 600-602.

30. Cosmides, L.; Tooby, J. Evolutionary Psychology: New Perspectives on Cognition and Motivation. Annu. Rev. Psychol. 2013, 64, 201-229. [CrossRef] [PubMed]

31. Buss, D.M. Evolutionary Psychology: The New Science of the Mind; Routledge: Oxfordshire, UK, 2019.

32. Wilson, M.; Daly, M.; Gordon, S. The Evolved Psychological Apparatus of Human Decision-Making is One Source of Environmental Problems. In Evolutionary Perspectives on Environmental Problems; Routledge: Oxfordshire, UK, 2017; pp. 31-52.

33. Mobbs, D.; Trimmer, P.C.; Blumstein, D.; Dayan, P. Foraging for foundations in decision neuroscience: Insights from ethology. Nat. Rev. Neurosci. 2018, 19, 419-427. [CrossRef] [PubMed]

34. Lynn, M.; Kampschroeder, K.; Pereira, A. Evolutionary perspectives on consumer behavior: An introduction. Adv. Consum. Res. $1999,26,226-230$.

35. Campbell, C. The puzzle of modern consumerism. In The Romantic Ethic and the Spirit of Modern Consumerism; Springer International Publishing: Cham, Switzerland, 2018; pp. 77-105. [CrossRef]

36. Otterbring, T.; Sundie, J.; Li, Y.J.; Hill, S. Evolutionary psychological consumer research: Bold, bright, but better with behavior. J. Bus. Res. 2020, 120, 473-484. [CrossRef]

37. Griskevicius, V.; Tybur, J.M.; Bergh, B.V.D. Going green to be seen: Status, reputation, and conspicuous conservation. J. Pers. Soc. Psychol. 2010, 98, 392-404. [CrossRef] [PubMed]

38. Saad, G.; Gill, T. Applications of evolutionary psychology in marketing. Psychol. Mark. 2000, 17, 1005-1034. [CrossRef]

39. Hantula, D.; Brockman, D.D.; Smith, C.L. Online Shopping as Foraging: The Effects of Increasing Delays on Purchasing and Patch Residence. IEEE Trans. Dependable Secur. Comput. 2008, 51, 147-154. [CrossRef]

40. Cohen, J.B.; Bernard, H.R. Evolutionary psychology and consumer behavior: A constructive critique. J. Consum. Psychol. 2013, 23, 387-399. [CrossRef]

41. Raheem, A.R.; Vishnu, P.A.R.M.A.R.; Ahmed, A.M. Impact of product packaging on consumer's buying behavior. Eur. J. Sci. Res. 2014, 122, 125-134.

42. Dawar, N.; Parker, P. Marketing universals: Consumers' use of brand name, price, physical appearance, and retailer reputation as signals of product quality. J. Mark. 1994, 58, 81-95.

43. Canessa, N.; Crespi, C.; Motterlini, M.M.P.; Baud-Bovy, G.; Chierchia, G.; Pantaleo, G.; Tettamanti, M.; Cappa, S. The Functional and Structural Neural Basis of Individual Differences in Loss Aversion. J. Neurosci. 2013, 33, 14307-14317. [CrossRef]

44. Marzilli Ericson, K.M.; Fuster, A. Expectations as endowments: Evidence on reference-dependent preferences from exchange and valuation experiments. Q. J. Econ. 2011, 126, 1879-1907. [CrossRef]

45. Morewedge, C.K.; Giblin, C.E. Explanations of the endowment effect: An integrative review. Trends Cogn. Sci. 2015, 19, 339-348. [CrossRef]

46. Morewedge, C.K.; Giblin, C.E.; Norton, M.I. The (perceived) meaning of spontaneous thoughts. J. Exp. Psychol. Gen. 2014, 143, 1742-1754. [CrossRef]

47. Peck, J.; Shu, S.B. The Effect of Mere Touch on Perceived Ownership. J. Consum. Res. 2009, 36, 434-447. [CrossRef]

48. Votinov, M.; Mima, T.; Aso, T.; Abe, M.; Sawamoto, N.; Shinozaki, J.; Fukuyama, H. The neural correlates of endowment effect without economic transaction. Neurosci. Res. 2010, 68, 59-65. [CrossRef] [PubMed]

49. Belk, R.W. Possessions and the Extended Self. J. Consum. Res. 1988, 15, 139-168. [CrossRef] 
50. Johnson, B.T.; Acabchuk, R.L. What are the keys to a longer, happier life? Answers from five decades of health psychology research. Soc. Sci. Med. 2018, 196, 218-226. [CrossRef] [PubMed]

51. Pantano, E.; Dennis, C.; Melewar, T. Technology, brand and people: Branding, identity, image and reputation in the emerging technology-mediated world. J. Bus. Res. 2020, 119, 410-411. [CrossRef]

52. Jussila, I.; Tarkiainen, A.; Sarstedt, M.; Hair, J.F. Individual psychological ownership: Concepts, evidence, and implications for research in marketing. J. Mark. Theory Pract. 2015, 23, 121-139. [CrossRef]

53. Beggan, J.K. On the social nature of nonsocial perception: The mere ownership effect. J. Pers. Soc. Psychol. 1992, 62, 229-237. [CrossRef]

54. Gawronski, B.; Bodenhausen, G.V.; Becker, A.P. I like it, because I like myself: Associative self-anchoring and post-decisional change of implicit evaluations. J. Exp. Soc. Psychol. 2007, 43, 221-232. [CrossRef]

55. Weiss, L.; Johar, G.V. Products as Self-Evaluation Standards: When Owned and Unowned Products Have Opposite Effects on Self-Judgment. J. Consum. Res. 2016, 42, 915-930. [CrossRef]

56. Paundra, J.; Rook, L.; van Dalen, J.; Ketter, W. Preferences for car sharing services: Effects of instrumental attributes and psychological ownership. J. Environ. Psychol. 2017, 53, 121-130. [CrossRef]

57. Escalas, J.E.; Bettman, J.R. Self-Construal, Reference Groups, and Brand Meaning. J. Consum. Res. 2005, 32, 378-389. [CrossRef]

58. Fournier, S. Consumers and Their Brands: Developing Relationship Theory in Consumer Research. J. Consum. Res. 1998, 24, 343-353. [CrossRef]

59. Atasoy, O.; Morewedge, C.K. Digital Goods Are Valued Less Than Physical Goods. J. Consum. Res. 2018, 44, 1343-1357. [CrossRef]

60. Siddiqui, S.; Turley, D. Extending the self in a virtual world. Adv. Consum. Res. 2006, 33, 647-648.

61. Bagga, P.; Joshi, A.; Hans, R. QoS based Web Service Selection and Multi-Criteria Decision Making Methods. Int. J. Interact. Multimedia Artif. Intell. 2019, 5, 113. [CrossRef]

62. Fritze, M.P.; Marchand, A.; Eisingerich, A.B.; Benkenstein, M. Access-Based Services as Substitutes for Material Possessions: The Role of Psychological Ownership. J. Serv. Res. 2020, 23, 368-385. [CrossRef]

63. Danckwerts, S.; Kenning, P. It's MY service, it's MY music: The role of psychological ownership in music streaming consumption. Psychol. Mark. 2019, 36, 803-816. [CrossRef]

64. Reb, J.; Connolly, T.; Connolly, T. Possession, feelings of ownership, and the endowment effect. Judgm. Decis. Mak. 2007, 2, 107-114.

65. Jai, T.-M.C.; Fang, D.; Bao, F.S.; James, R.N., III; Chen, T.; Cai, W. Seeing It Is Like Touching It: Unraveling the Effective Product Presentations on Online Apparel Purchase Decisions and Brain Activity (An fMRI Study). J. Interact. Mark. 2021, 53, 66-79. [CrossRef]

66. Huang, Y.; Wang, L.; Shi, J. When Do Objects Become More Attractive? The Individual and Interactive Effects of Choice and Ownership on Object Evaluation. Pers. Soc. Psychol. Bull. 2009, 35, 713-722. [CrossRef]

67. Morewedge, C.K.; Gray, K.; Wegner, D.M. Perish the Forethought: Premeditation Engenders Misperceptions of Personal Control. Self. Control Soc. Mind Brain 2010, 2010, 260-278. [CrossRef]

68. Ryan, T. Walgreens Tests Tech That Sort of Recognizes You In-Store. RetailWire 2019. Available online: https: / /www.retailwire. com/discussion/walgreens-tests-tech-that-sort-of-recognizes-you-in-store/ (accessed on 30 July 2021).

69. Whaling, P. Interview: How The Container Store Is Reinventing The ‘Big Box” Experience For The Next Generation.' PSFK 2019. Available online: https://www.psfk.com/2019/02/interview-frch-store-design-the-container-store.html?curator=MediaREDEF (accessed on 30 July 2021).

70. PSFK. Levi's Experiential Flagship Store 2018. Available online: https://www.psfk.com/2018/11/levis-flagship-experientialstore.html (accessed on 18 January 2021).

71. Norton, M.I.; Mochon, D.; Ariely, D. The IKEA effect: When labor leads to love. J. Consum. Psychol. 2012, 22, 453-460. [CrossRef]

72. Dohle, S.; Rall, S.; Siegrist, M. I cooked it myself: Preparing food increases liking and consumption. Food Qual. Preference 2014, 33, 14-16. [CrossRef]

73. Troye, S.V.; Supphellen, M. Consumer Participation in Coproduction: "I Made it Myself" Effects on Consumers' Sensory Perceptions and Evaluations of Outcome and Input Product. J. Mark. 2012, 76, 33-46. [CrossRef]

74. Franke, N.; Schreier, M.; Kaiser, U. The "I Designed It Myself" Effect in Mass Customization. Manag. Sci. 2010, 56, 125-140. [CrossRef]

75. Kinjo, K.; Ebina, T. Paradox of choice and consumer nonpurchase behavior. AI Soc. 2014, 30, 291-297. [CrossRef]

76. Schwartz, B. The Paradox of Choice—Why More Is Less; Harper Perrenial: New York, NY, USA, 2004.

77. Chernev, A.; Böckenholt, U.; Goodman, J. Choice overload: A conceptual review and meta-analysis. J. Consum. Psychol. 2015, 25, 333-358. [CrossRef]

78. Hills, T.T.; Noguchi, T.; Gibbert, M. Information overload or search-amplified risk? Set size and order effects on decisions from experience. Psychon. Bull. Rev. 2013, 20, 1023-1031. [CrossRef] [PubMed]

79. Zimmerman, F.J.; Shimoga, S.V. The effects of food advertising and cognitive load on food choices. BMC Public Heal. 2014, 14, 342. [CrossRef] [PubMed]

80. Hafner, R.J.; White, M.P.; Handley, S.J. Spoilt for choice: The role of counterfactual thinking in the excess choice and reversibility paradoxes. J. Exp. Soc. Psychol. 2012, 48, 28-36. [CrossRef] 
81. Whitley, S.C.; Trudel, R.; Kurt, D. The Influence of Purchase Motivation on Perceived Preference Uniqueness and Assortment Size Choice. J. Consum. Res. 2018, 45, 710-724. [CrossRef]

82. Ariely, D.; Silva, J. Payment method design: Psychological and economic aspects of payments. Cent. E-Bus MIT Pap. 2002, 196, 68-73.

83. Mazar, N.; Plassmann, H.; Robitaille, N.; Lindner, A. Pain of Paying?-A Metaphor Gone Literal: Evidence from Neural and Behavioral Science. Rotman School of Management Working Paper No. 2901808. Available online: https://papers.ssrn.com/sol3/papers. cfm?abstract_id=29018082016 (accessed on 10 September 2021).

84. Hafalir, E.I.; Loewenstein, G.F. The impact of credit cards on spending: A field experiment. SSRN Electron. J. 2011, 1-29. [CrossRef]

85. Lo, H.-Y.; Harvey, N. Shopping without pain: Compulsive buying and the effects of credit card availability in Europe and the Far East. J. Econ. Psychol. 2011, 32, 79-92. [CrossRef]

86. See-To, E.W.; Ngai, E.W. An empirical study of payment technologies, the psychology of consumption, and spending behavior in a retailing context. Inf. Manag. 2019, 56, 329-342. [CrossRef]

87. Prelec, D.; Simester, D. Always Leave Home Without It: A Further Investigation of the Credit-Card Effect on Willingness to Pay. Mark. Lett. 2001, 12, 5-12. [CrossRef]

88. Lapuz, J.; Griffiths, M.D. The role of chips in poker gambling: An empirical pilot study. Gambl. Res. J. Natl. Assoc. Gambl. Stud. 2010, 22, 34-39.

89. Prelec, D.; Loewenstein, G. The Red and the Black: Mental Accounting of Savings and Debt. Mark. Sci. 1998, 17, 4-28. [CrossRef]

90. Pisani, F.; Atalay, S. Cashless payments, pain of paying and the role of attachment. Adv. Consum. Res. 2018, 11, 238-239.

91. Ong, T. KFC in China Tests Letting People Pay by Smiling. The Verge 2017. Available online: https://www.theverge.com/2017/9 /4/16251304/kfc-china-alipay-ant-financial-smile-to-pay (accessed on 18 January 2021).

92. Loewenstein, G.; Sunstein, C.R.; Golman, R. Disclosure: Psychology Changes Everything. Annu. Rev. Econ. 2014, 6, 391-419. [CrossRef]

93. Kamleitner, B.; Erki, B. Payment method and perceptions of ownership. Mark. Lett. 2012, 24, 57-69. [CrossRef]

94. Runnemark, E.; Hedman, J.; Xiao, X. Do consumers pay more using debit cards than cash? Electron. Commer. Res. Appl. 2015, 14, 285-291. [CrossRef]

95. Soetevent, A.R. Payment Choice, Image Motivation and Contributions to Charity: Evidence from a Field Experiment. Am. Econ. Journal: Econ. Policy 2011, 3, 180-205. [CrossRef]

96. Soman, D. Effects of Payment Mechanism on Spending Behavior: The Role of Rehearsal and Immediacy of Payments. J. Consum. Res. 2001, 27, 460-474. [CrossRef]

97. Thaler, R. Some empirical evidence on dynamic inconsistency. Econ. Lett. 1981, 8, 201-207. [CrossRef]

98. Loewenstein, G. Anticipation and the Valuation of Delayed Consumption. Econ. J. 1987, 97, 666-684. [CrossRef]

99. Redelmeier, N.A.; Heller, D.N. Time Preference in Medical Decision Making and Cost—Effectiveness Analysis. Med. Decis. Mak. 1993, 13, 212-217. [CrossRef] [PubMed]

100. Benzion, U.; Rapoport, A.; Yagil, J. Discount Rates Inferred from Decisions: An Experimental Study. Manag. Sci. 1989, 35, 270-284. [CrossRef]

101. Green, L.; Fristoe, N.; Myerson, J. Temporal discounting and preference reversals in choice between delayed outcomes. Psychon. Bull. Rev. 1994, 1, 383-389. [CrossRef] [PubMed]

102. Green, L.; Fry, A.F.; Myerson, J. Discounting of Delayed Rewards: A Life-Span Comparison. Psychol. Sci. 1994, 5, 33-36. [CrossRef]

103. Ingene, C.A. Productivity and functional shifting in spatial retailing-private and social perspectives. J. Retail. 1984, 60, 15-36.

104. Granzin, K.L.; Painter, J.J.; Valentin, E. Consumer logistics as a basis for segmenting retail markets: An exploratory inquiry. J. Retail. Consum. Serv. 1997, 4, 99-107. [CrossRef]

105. Gupta, A.; Su, B.-C.; Walter, Z. An Empirical Study of Consumer Switching from Traditional to Electronic Channels: A PurchaseDecision Process Perspective. Int. J. Electron. Commer. 2004, 8, 131-161. [CrossRef]

106. Burke, R.R. Technology and the Customer Interface: What Consumers Want in the Physical and Virtual Store. J. Acad. Mark. Sci. 2002, 30, 411-432. [CrossRef]

107. Meuter, M.L.; Ostrom, A.L.; Roundtree, R.I.; Bitner, M.J. Self-Service Technologies: Understanding Customer Satisfaction with Technology-Based Service Encounters. J. Mark. 2000, 64, 50-64. [CrossRef]

108. Alcañiz, M.; Bigné, E.; Guixeres, J. Virtual Reality in Marketing: A Framework, Review, and Research Agenda. Front. Psychol. 2019, 10, 1530. [CrossRef]

109. Knutson, B.; Wimmer, G.E.; Rick, S.; Hollon, N.G.; Prelec, D.; Loewenstein, G. Neural Antecedents of the Endowment Effect. Neuron 2008, 58, 814-822. [CrossRef]

110. Meuter, M.L.; Bitner, M.J.; Ostrom, A.L.; Brown, S.W. Choosing among Alternative Service Delivery Modes: An Investigation of Customer Trial of Self-Service Technologies. J. Mark. 2005, 69, 61-83. [CrossRef]

111. Fenech, T.; O'Cass, A. Internet users' adoption of Web retailing: User and product dimensions. J. Prod. Brand Manag. 2001, 10, 361-381. [CrossRef]

112. Choudhary, A.S. Investigation of Consumers Waiting in Line at a Fashion Store. BEST Int. J. Humanit. Arts Med. Sci. 2016, 4, 83-88.

113. Kirby, K.N. Bidding on the future: Evidence against normative discounting of delayed rewards. J. Exp. Psychol. Gen. 1997, 126, 54-70. [CrossRef] 
114. Frederick, S.; Loewenstein, G.; O’Donoghue, T. Time discounting and time preference: A critical review. Time Decis. Econ. Psychol. Perspect Intertemporal Choice 2003, 40, 13-86. [CrossRef]

115. Babin, B.J.; Darden, W.R.; Griffin, M. Work and/or Fun: Measuring Hedonic and Utilitarian Shopping Value. J. Consum. Res. 1994, 20, 644-656. [CrossRef]

116. Wedel, M.; Bigné, E.; Zhang, J. Virtual and augmented reality: Advancing research in consumer marketing. Int. J. Res. Mark. 2020, 37, 443-465. [CrossRef]

117. Reuters. Humanoid Robot Starts Work at Japanese Department Store. Reuters 2015. Available online: https://www.reuters.com/ article/us-japan-robot-store-idUSKBN0NB1OZ20150420 (accessed on 30 July 2021).

118. Sun, J.J.; Bellezza, S.; Paharia, N. Buy Less, Buy Luxury: Understanding and Overcoming Product Durability Neglect for Sustainable Consumption. J. Mark. 2021, 85, 28-43. [CrossRef]

119. Handfield, R.; Ghosh, S.; Fawcett, S. Quality-Driven Change and its Effects on Financial Performance. Qual. Manag. J. 1998, 5, 13-30. [CrossRef]

120. Garvin, D.A. Product quality: An important strategic weapon. Bus. Horizons 1984, 27, 40-43. [CrossRef]

121. Jacobson, R.; Aaker, D.A. The Strategic Role of Product Quality. J. Mark. 1987, 51, 31. [CrossRef]

122. Erdem, T.; Swait, J.; Louviere, J. The impact of brand credibility on consumer price sensitivity. Int. J. Res. Mark. 2002, 19, 1-19. [CrossRef]

123. Teller, C.; Reutterer, T.; Schnedlitz, P. Hedonic and utilitarian shopper types in evolved and created retail agglomerations. Int. Rev. Retail. Distrib. Consum. Res. 2008, 18, 283-309. [CrossRef]

124. Rindova, V.P.; Williamson, I.; Petkova, A.P.; Sever, J.M. Being Good or Being Known: An Empirical Examination of the Dimensions, Antecedents, and Consequences of Organizational Reputation. Acad. Manag. J. 2005, 48, 1033-1049. [CrossRef]

125. Kahneman, D. Thinking, Fast and Slow; Macmillan: New York, NY, USA, 2011.

126. Kahneman, D.; Knetsch, J.L.; Thaler, R.H. Experimental Tests of the Endowment Effect and the Coase Theorem. J. Politi-Econ. 1990, 98, 1325-1348. [CrossRef]

127. Novemsky, N.; Kahneman, D. The Boundaries of Loss Aversion. J. Mark. Res. 2005, 42, 119-128. [CrossRef]

128. Ma, S. Fast or free shipping options in online and Omni-channel retail? The mediating role of uncertainty on satisfaction and purchase intentions. Int. J. Logist. Manag. 2017, 28, 1099-1122. [CrossRef]

129. Cao, Y.; Ajjan, H.; Hong, P. Post-purchase shipping and customer service experiences in online shopping and their impact on customer satisfaction: An empirical study with comparison. Asia Pac. J. Mark. Logist. 2018, 30, 400-416. [CrossRef]

130. Huang, W.-H.; Shen, G.C.; Liang, C.-L. The effect of threshold free shipping policies on online shoppers' willingness to pay for shipping. J. Retail. Consum. Serv. 2019, 48, 105-112. [CrossRef] 